\title{
NUTRITIONAL CHARACTERIZATION OF GRAIN AMARANTH GROWN IN NIGERIA FOR FOOD SECURITY AND HEALTHY LIVING
}

\author{
${ }^{1}$ Abolaji, G.T.* ${ }^{1}$ Olooto, F. M., ${ }^{2}$ Ogundele, D. T., and ${ }^{3}$ Williams, F. E. \\ ${ }^{1}$ Department of Agricultural Economics and Extension Service, College of Agriculture and \\ Veterinary Medicine, Kwara State University, Malete, Nigeria \\ 2Department of Chemical, Geological and Physical Sciences Chemistry Unit, Kwara State \\ University, Malete, Nigeria \\ ${ }^{3}$ Department of Clinical Pharmacy and Pharmacy practice, University of Ilorin, Ilorin, Nigeria. \\ *Corresponding author Email: drgracea@hotmail.com or grace.abolaij@kwasu.edu.ngPhone \\ no: +2348160786999
}

\begin{abstract}
Amaranths cruentus is a flowering plant species that yields the nutritious staple amaranth grain. Zinc in grain amaranth is reported to contribute to boosting the immune system and iron is required by enzymes for oxygen metabolism. This study is to exploit the multi-benefits of amaranth which ranged from improved well-being to recovery of severely malnourished children; increased body mass index of people formerly wasted by HIVIAIDS; environmental adaptability, yield, and recipes development. The study focused on determining the nutritional and medicinal properties of grain amaranth cultivar obtained from Rural Extension with Africa Poor (REAP) in Kenya which was propagated in Kwara State, Nigeria, harvested after 65 days, and prepared as samples for the study. Standard procedures of Association of Official Analytical Chemists (AOAC), Atomic Absorption Spectrophotometer, Flame Photometer, and Spectrophotometer were used to determine the macro/micronutrients in the grains. Results revealed that the grains contained protein, lipid, Iron-66 mg/100g, Zinc-11.34 $\mathrm{mg} / 100 \mathrm{~g}$, Calcium- $78.7 \mathrm{mg} / 100 \mathrm{~g}$, Manganese- $37.1 \mathrm{mg} / 100 \mathrm{~g}$, Magnesium- $2845 \mathrm{mg} / 100 \mathrm{~g}$, Potassium-400 mg/100g; Thiamine-0.2756 mg (\%), Riboflavin-0.734 mg (\%) and Niacin1.042. More research efforts are needed on growing, inclusion in diets, consumer behavior and market acceptability of Amaranth cruentus based products in order to contribute to the efforts of addressing food security, poverty reduction, nutritional, and medicinal needs of vulnerable communities.
\end{abstract}

Keywords: Complementary Food, Cultivar, Macro/micronutrients, Recipes, Well-being. 


\section{INTRODUCTION}

Alternative crops are plant species that are used traditionally for their food, fiber, fodder, oil or medicinal properties. They have an under-exploited potential to contribute to food security, nutrition, health, income generation and environmental services. The pseudo cereal grain amaranth (Amaranthus cruentus) is one of such alternative crops. Grain amaranth is a fast growing, high yielding, stress resistant, nutritious crop with potential to contribute to the alleviation of poverty and malnutrition.

As indicated by Tung (2010), amaranth green leaves are commonly eaten boiled by many countries in West Africa. Its mild flavor and tender texture complements many starchy dishes and as a nutritious vegetable, amaranth leaves are high in vitamins $A, K, B 6, C$, riboflavin and foliate; and essential minerals including calcium, iron, magnesium, phosphorus, potassium, zinc, copper, and manganese. Due to its high iron content, it is recommended for those at risk for anemia and as an important source of protein, some African populations rely on amaranth leaves for as much as 25 percent of their daily protein intake during its growing season. With a toasted flavor similar to popcorn when cooked, amaranth seeds are small in size but a good source of carbohydrate and protein (15-17 percent by weight). It is rich in the amino acids methionine, cycteine and has the highest content of lysine compared with all grains. It also has three times the fiber of wheat.

In the Home Remedies report (2008), it was pointed out that amaranth has various health benefits and medicinal properties which include but not limited to preventing retarded growth in children, increasing the flow of breast milk, preventing premature ageing, important in all bleeding tendencies, treating leucorrhoea, considered highly beneficial in treatment of gonorrhea and benefits patients with cardiovascular disease. According to Agong (2006), grain amaranths are traditionally used in medicine, folk festivals, and as dye sources in South Africa. Bink and Belay (2006) also reported that East African countries like Ethiopia and Peru, grain amaranth also used the grains as food; preparation of local beverage; added into porridge; and ground seeds are mixed with other grains to prepare pancake-like bread.

Consumption of grain amaranth is reported to have nutritional and health benefits. This range from a general improvement in well-being to prevention and improvement of specific ailments and symptoms including recovery of severely malnourished children and an increase in the body mass index of people formerly wasted by HIVIAIDS (Tagwira et al., 2006). According to Martirosyan et al. (2007), the inclusion of amaranth oil in the diet contributes to an increase in 
the concentration of polyunsaturated fatty acids and effective natural antioxidant supplement capable of protecting cellular membranes against oxidative damage. Thus, the nutritional value of amaranth and environmental adaptability creates an excellent potential for the crop to positively impact on thousands of poor farmers who rely on staple crops that are often neither resilient nor nutritious (Mburu et al., 2012).

The total unsaturated acids ranged from $76.2 \%$ to $77.6 \%$ and saturated fatty acids $22.4 \%$ to $22.8 \%$.Amaranth oil provides an excellent source for omega series fatty acids and can therefore be recommended as a functional food product for the prevention and treatment of cardiovascular diseases. Also, FAO/WHO (2002) joint report indicated that the presence of high levels of unsaturated fatty acids (oleic and linoleic) plus the high protein content in grain amaranth makes it a balanced grain.

Despite the medicinal and nutritional values of the grains, its production and consumption in Nigeria is dismal. This research seeks to promote the need for production and utilization of grain amaranth in Kwara state Nigeria, as a strategy to improve food security and nutrition. Also, the grain amaranth has a prominent role in human health and this study was, therefore, initiated to know the proximate composition, mineral and vitamin contents of grains amaranth in order to evaluate its nutritional and medicinal importance.

\section{MATERIALS AND METHODS}

\section{Materials}

Seeds of grain amaranth obtained from REAP Nairobi Kenya was planted in llorin Kwara State Nigeria. Following Yarger (2008) and REAP (2013) guidelines of propagation, harvesting and processing, grain was harvested after 65 days (about 10 weeks) after propagation.

\section{Method}

To obtain samples for the proximate composition, mineral and vitamins analysis, the harvested grains was dried and ground to powdered form by using grinder. The proximate composition was determined by bringing the samples to uniform size and analyzed for moisture, protein, fat, ash, fiber and carbohydrate by the methods of AOAC (2003). The Moisture was determined by oven drying method. $1.5 \mathrm{~g}$ of well-mixed sample was accurately weighed in clean, dried crucible (W1). The crucible was introduced into an oven at $100-105^{\circ} \mathrm{C}$ for 6-12 Hours until a constant weight was obtained. Then the crucible was placed in 
desiccators for 30 Minutes to cool. After cooling, it was weighed again (W2). The percentage moisture was calculated as follows:

$$
\% \text { Moisture }=\mathrm{W} 1-\mathrm{W} 2 \times 100 / \mathrm{Wt} \text {. of sample }
$$

Where

W1 $=$ Initial weight of crucible + Sample

W2 = Final weight of crucible + Sample

Note: Moisture free samples were used for further analysis.

For the determination of ash, clean empty crucible was placed in a muffle furnace at $600^{\circ} \mathrm{C}$ for an hour, cooled in desiccator and then weight of empty crucible was noted (W1 ). One gram of each of sample was taken in crucible (W2). The sample was ignited over a burner with the help of blowpipe, until it is charred. Then the crucible was placed in muffle furnace at $550^{\circ} \mathrm{C}$ for 2-4 hr. The appearances of gray white ash indicate complete oxidation of all organic matter in the sample. The crucible was cooled and weighed (W3). Percent ash was calculated

$$
\% \text { Ash }=\text { Difference in wt. of Ash } \times 100
$$

Difference in wt. of ash $=$ W3 $-\mathrm{W} 1$

Protein in the sample was determined by Kjeldahl method. $0.5-1.0 \mathrm{~g}$ of dried sample was taken in digestion flask. $10-15 \mathrm{ml}$ of concentrated $\mathrm{H}_{2} \mathrm{SO}_{4}$ and $8 \mathrm{~g}$ of digestion mixture of $\mathrm{K}_{2} \mathrm{SO}_{4}$ and $\mathrm{CuSO}_{4}$ (8:1) were added. The flask was swirled in order to mix the contents thoroughly then placed on heater to start digestion till the mixture become clear (turquoise blue in color) for $2 \mathrm{hrs}$. The digest was cooled and transferred to $100 \mathrm{ml}$ volumetric flask and additional distilled water was added to mark up to $100 \mathrm{ml}$. Distillation of the digest was performed. Ten milliliters of digest was introduced in the distillation tube and then $10 \mathrm{ml}$ of $0.5 \mathrm{~g}$ of NaOH was gradually added through the same way. Distillation was continued for at least 10 minutes and $\mathrm{NH}_{3}$ produced was collected as $\mathrm{NH}_{4} \mathrm{OH}$ in a conical flask containing $20 \mathrm{ml}$ of $4 \%$ boric acid solution with few drops of modified methyl red indicator. During distillation yellowish color appears due to $\mathrm{NH}_{4} \mathrm{OH}$. The distillate was then titrated against standard $0.1 \mathrm{NH}_{4} \mathrm{Cl}$ solution till the appearance of pink color. A blank was also run through all steps as above. Percentage crude protein content of the sample was calculated by using the following formula:

$\%$ Crude Protein $=6.25^{*} \times \% \mathrm{~N}\left({ }^{*}\right.$. Correction factor $)$

$\% \mathrm{~N}=(\mathrm{S}-\mathrm{B}) \times \mathrm{N} \times 0.014 \times \mathrm{D} \times 100 /$ wt. of sample $\times \mathrm{V}$

Where

$S=$ Sample titration reading

$\mathrm{B}=$ Blank titration reading 
$\mathrm{N}=$ Normality of $\mathrm{HCl}$

$\mathrm{D}=$ Dilution of sample after digestion

$\mathrm{V}=$ Volume taken for distillation

$0.014=$ Milli equivalent weight of Nitrogen

Dry extraction method for fat determination was employed. It involved extracting dry sample with cold ethanol solvent since all the fat materials e.g. fats, phospholipids, sterols, fatty acids, carotenoids, pigments, chlorophyll etc. are extracted together, the results are frequently referred to as crude fat. Fats were determined by intermittent Soxhlet extraction apparatus. Crude fat was determined by ether extract method using Soxhlet apparatus. Approximately $1 \mathrm{~g}$ of moisture free sample was wrapped in filter paper, placed in fat free thimble and then introduced in the extraction tube. Weighed, cleaned and dried receiving beaker was filled with petroleum ether and fitted into the apparatus. Water and heater were turned on to start extraction. After 6 siphoning, ether was allowed to evaporate and the beaker was disconnected before last siphoning. The extract was washed with ether, transferred into clean glass dish and was evaporated on water bath. The dish was placed in an oven at $105^{\circ} \mathrm{C}$ for 2 hours and cooled in desiccator. The percentage crude fat was determined.

$\%$ Crude Fat $=$ wt. of ether extract $\times 100 / w t$. of sample

A moisture free and ether extracted sample of crude fiber made of cellulose was first digested with dilute $\mathrm{H}_{2} \mathrm{SO}_{4}$ and then with dilute $\mathrm{KOH}$ solution. The undigested residue collected after digestion was ignited and loss in weight after ignition was registered as crude fiber.

Nitrogen Free Extract (NFE) was calculated by difference after analysis of all the other items' method in the proximate analysis.

NFE $=(100-\%$ moisture $+\%$ crude protein $+\%$ crude fat

$+\%$ crude fiber $+\%$ ash)

The percentage calories in selected sample was calculated by multiplying the percentage of crude protein and carbohydrate with 4 and crude fat with 9 . The values were then converted to calories per $100 \mathrm{gm}$ of the sample.

Mineral contents of grain amaranth were determined using the standard AOAC procedure (AOAC, 2003). 


\section{RESULTS AND DISCUSSION}

\section{Proximate composition of raw amaranth grains:}

As shown in Table 1, the grain amaranth in this study is rich in proteins (19.85\%); carbohydrate (77.82\%); ash (2.25\%); dietary fiber (1.81\%); fat (1.79\%); and energy (322 $\mathrm{kcal} / 100 \mathrm{~g})$. The proximate composition values obtained in this study are similar to those of Stephen, et al., (2013).

Table 1: proximate composition of Grain Amaranth

\begin{tabular}{lc} 
Nutrient & \% composition \\
\hline Moisture & 6.49 \\
Ash & 2.25 \\
Protein & 19.85 \\
Fat & 1.79 \\
Dietary Fiber & 1.81 \\
Carbohydrates & 77.82 \\
Energy & $322 \mathrm{kcal} / 100 \mathrm{~g}$ \\
\hline Source: AOAC (2003) & \% composition= Average of 3 replicates
\end{tabular}

As concluded in Stephen, et al., (2013) findings, the contents of carbohydrates, fats, and protein in amaranth provide balanced nutrients with less amount of consumption compared to other cereals. Also, Tagwira et al., (2006) reported that consumption of grain amaranth provide nutritional and health benefits that include general improvement in well-being of severely malnourished children; prevention and improvement of specific ailments and symptoms exhibited by people that were wasted by HIVIAIDS; and increase in their body mass index. Thus, the proximate content of protein, carbohydrate, fat, ash and energy showed that the grain amaranth in this study was loaded with balanced nutrients that could enhance healthy living and food security.

\section{Mineral composition of raw amaranth grain:}

As shown in Table 2, the Zinc $(11.30 / 100 \mathrm{~g})$ and manganese $(5.71 / 100 \mathrm{~g})$ values obtained in this study were similar or better than those of Stephen et al., (2013) study with zinc (3.6 $4.0 \mathrm{mg} / 100 \mathrm{~g})$ and manganese $(5.9-6.8 \mathrm{mg} / 100 \mathrm{~g})$. As they indicated, people with AIDS are almost universally deficient of zinc, which contributes significantly to the continued decline of their already damaged immune systems. Therefore, consumption of grain amaranth could 
stabilize their immune function and reduce complications from the disease. Also, the results in this study showed that the amaranth grain specie is a good source of iron $(66.00 \mathrm{mg} / 100 \mathrm{~g})$ compared with the $16.8-21.0 \mathrm{mg} / 100 \mathrm{~g}$ of amaranth grain specie studied by Stephen et al., (2013) and iron (13.0 mg/100g) obtained by Mburu, et al., (2012) and for zinc (4.8 mg/100g). Tagwira et al., (2006) pointed out that Iron is required by a number of enzymes for oxygen metabolism. Its deficiency reduces their oxygen-carrying capacity and interferes with aerobic functions that could result into anemia and ill health conditions. Thus, the grain amaranth in this study is loaded with iron that could alleviate anemia and other associated ill health conditions. Other minerals of importance in the grain amaranth identified in this study included potassium (400.50 mg/100g); calcium (178.70 mg/100g); and magnesium (284.50 $\mathrm{mg} / 100 \mathrm{~g}$ ) which were higher values except for calcium. Mburu, et al. (2012) grain amaranth product had potassium $(324.4 \mathrm{mg} / 100 \mathrm{~g})$, calcium $(189.1 \mathrm{mg} / 100 \mathrm{~g})$, magnesium $(219.5$ $\mathrm{mg} / 100 \mathrm{~g}$ ). They concluded that considering amaranth grain product fed to infant three times a day, at a reconstitution of $15 \%$ product, the levels of magnesium, manganese and tocopherols were far above the recommended intakes. Thus, the grain amaranth in this study is loaded with essential minerals especially zinc and iron that could stabilize immune and anemia functions that could reduce complications from HIVIAIDS and anemia diseases respectively. It is also loaded with magnesium and manganese that are crucial for infants growth and development.

Table 2: Mineral composition of Grain Amaranth

\begin{tabular}{lc}
\hline Minerals & Amount in $\mathrm{mg} / 100 \mathrm{~g}$ \\
\hline Iron & 66.00 \\
Zinc & 11.30 \\
Calcium & 178.70 \\
Magnesium & 284.50 \\
Manganese & 5.71 \\
Potassium & 400.50
\end{tabular}

Source: AOAC (2003) Amount in $\mathrm{mg} / 100 \mathrm{~g}=$ Average of 3 replicates. 


\section{Vitamin composition of raw amaranth grain:}

Table 3: Vitamins in Grain Amaranth

\begin{tabular}{lc} 
Vitamin & $\mathrm{mg} \%$ \\
\hline Thiamin & 0.276 \\
Riboflavin & 0.734 \\
Niacin & 1.042 \\
\hline Source: AOAC (2003) & $\mathrm{mg} \%=$ Average of 3 replicates.
\end{tabular}

Niacin concentration was $0.9 \mathrm{mg} / 100 \mathrm{~g}$ sample which was similar to the value reported for A. cruentus by other researchers (FAO/WHO, 2002 and Martirosyan, et al., 2007). The value of thiamine, riboflavin and Niacin in this study were higher compared to the value reported by these same researchers. Thus, the grain amaranth in this study is loaded with Niacin that is important for proper blood circulation and the healthy functioning of the nervous system; helps to maintain the normal functions of the gastro-intestinal tract and proper metabolism of proteins and carbohydrates; and also helps to maintain a healthy skin and dilates the blood capillary system. Thiamin (vitamin B1), a water-soluble vitamin that is needed by infants to help the body release energy from carbohydrates during metabolism and plays a vital role in the normal functioning of the nervous system.

\section{CONCLUSIONS}

Based on the results obtained in this study and comparison with other researchers' scientific findings, the following conclusions were made:

The grain amaranth in this study is loaded with protein, carbohydrate, fat, ash and energy that could provide balanced nutrients to enhance food security and healthy living. It contains essential minerals especially zinc and iron that could stabilize immune and alleviate anemic conditions respectively; and loaded with magnesium and manganese that are crucial for infants growth and development. The content levels of thiamine, riboflavin and Niacin in the grain amaranth in this study could enhance proper blood circulation; healthy functioning of the nervous system; maintenance of normal functions of the gastro-intestinal tract and proper metabolism of proteins and carbohydrates; and maintenance of healthy skin and dilation of blood capillary system. 


\section{RECOMMENDATIONS}

Based on the results obtained in this study and comparison with other researchers' scientific findings, the following recommendations were made:

1. Growing of grain amaranth should be encouraged at both household and community levels to enhance the nutritional and healthy living status of the populace toward foods security in Nigeria.

2. Inclusion of grain amaranth in diets production of high protein-energy weaning food using grain Amaranth are recommended for adult and infants respectively.

\section{REFERENCES}

Agong, S. G., (2006): Amaranthus caudatus L. [Internet] Record from PROTA4U. M. Brink, and G. Belay, eds. PROTA (PlantResources of Tropical Africa / Ressources v_eg_etales de l'Afrique tropicale), Wageningen, Netherlands. http://www. prota4u.org/search.asp. Accessed 22 October 2014.

AOAC, 2003. Official Methods of Analysis of the Association of Official Analytical Chemists, $17^{\text {th }}$ edition. Association of Official Analytical Chemists, Arlington, Virginia.

Bink M, Belay G (2006). Cereals and pulses. WUR, The Netherlands. Birch GG, Spencer M, Cameron AG (1980). Food science, Oxford, UK: Pergamon Press (2nd ed., pp.29$37)$.

Centeotl (2002). Amaranth: Ancient food of the gods for the people of today. Nutritional value. [Online]. Available at: http://prodigyweb.net.mx/centeotlac/eng/pages/valor.htm (Accessed on 5/ 4/2006).

Dhellot JR, Matouba MG, Maloumbi JM, Nzikou DG, Linder M, Desobry S, Parmentier M (2006). Extraction, chemical composition and nutritional characterization of vegetable oils: Case of Amaranthus hybridus (var 1 and 2) of Congo Brazzaville. Afr. J. Biotechnol. (5):1095-1101.

FAO/WHO (2002). Thiamin, riboflavin, niacin, vitamin B6, pantothenic acid and biotin. In: Human Vitamin and Mineral Requirements, Report of a Joint FAO/WHO Expert Consultation, FAO, Rome,; 3: 27-30.

Gardner Amanda (2014). 18 Health Benefits Of Whole Grains www. huffingtonpost.com Posted: 08/10/2014 12:22 pm EDT Updated: 08/13/2014 11:59 am EDT

Home Remedies (2008). Herbal medicines and amaranth. Retrieved on March 28, 2012, from:http://www.best-home-remedies.com/herbalmedicine/vegetables lamaranth.htm. Accessed 22 October 2014. Accessed 22 October 2014. 
Martirosyan DM, Miroshnichenko LA, Kulakova SN, Pogojeva AV and VI Zoloedov (2007). Amaranth oil application for coronary heart disease and hypertension, Lipids In Health and Disease,; 6: 10-11.

Mburu MW, Gikonyo NK, Kenji GM and AM Mwasaru (2012). Nutritional and Functional properties of a Complementary Food Based on Kenyan Amaranth Grain (Amaranthus cruentus). African Journal of Food Agriculture, Nutrition and Development; 12 (2): 1-19.

Mnkeni AP, Masika P, Maphaha M (2007). Nutritional quality of vegetable and seed from different accessions of Amaranthus in South Africa. Paper presented at the International Symposium on the Nutritional Value and Water Use of Indigenous Crops for Improved Livelihoods held on 19th and 20th September 2006 at the University of Pretoria in Pretoria, South Africa. Water SA 33(2):377-380.

Stephen Kariuki, Daniel Sila, Glaston Kenji (2013). Nutritional Profile of Amaranth Grain Varieties Grown in Kenya. Food Science and Quality Management www.iiste.org ISSN 2224-6088 (Paper) ISSN 2225-0557 (Online) Vol.17

Tagwira, M., Tagwira, F. Dugger, R., Okum, B. 2006. Using grain amaranth to fight malnutrition. RUFORUM working document 1: 201-206.

Tung A. (2010). Amaranth: Food Production without Attention. Nourishing the Planet Project, http://blogs.worldwatch.org/amaranth-food-production-without-attention/

Yarger L. (2008). Amaranth Grain \& Vegetable Types. ECHO Technical Note. 17391 Durrance Road, North Fort Myers, FL 33917, USA. www.echonet.org. 